\title{
Insiders but Outsiders: The Struggle for the Inclusion of Asylum Seekers and Refugees in South Africa
}

\author{
M. Florencia Belvedere
}

\section{Abstract}

This article examines the politics of urban refugees in South Africa. It shows that despite South Africa's adoption of an encompassing rights-regarding legal framework that has the potential to be inclusive towards asylum seekers and refugees in the country and afford them basic human rights and protection, asylum seekers and refugees nonetheless remain "internally excluded," predominantly as a result of practices adopted by a nationalist Department of Home Affairs to implement refugee legislation and by the UNHCR in its quest to prioritize the safeguarding of the institution of asylum. The article also shows how the adoption of these practices has been facilitated by a construction of asylum seekers and refugees as "bogus" claimants who have no place in post-apartheid South Africa.

\section{Résumé}

Cet article examine la politique sur les réfugiés urbains en Afrique du Sud. Il démontre que malgré l'adoption par l'Afrique du Sud d'un cadre juridique englobant le respect des droits, qui a le potentiel d'être inclusif envers les demandeurs d'asile et les réfugiés dans le pays et de leur assurer les droits fondamentaux et la protection, les demandeurs d'asile et les réfugiés restent néanmoins des " exclus internes", principalement en raison des pratiques adoptées dans l'implémentation de la législation concernant les réfugiés par un Département des affaires intérieures nationaliste, et par le HCR, dans sa quête de privilégier la sauvegarde de l'institution du droit d'asile. L'article démontre aussi comment l'adoption de ces pratiques a été facilitée par le fait de dépeindre les deman- deurs d'asile et les réfugiés comme de "faux" demandeurs n'ayant pas leurs places dans une Afrique du Sud post apartheid.

\section{Introduction}

In a society like ours which prides itself on its noble sentiments, [the treatment of refugees] is shameful. As South Africans we are justifiably proud of our country and of our democracy which has just celebrated its tenth birthday. We are proud of those policies which are enshrined in the Constitution, a constitution which is unparalleled in Africa, and indeed equals those of the most advanced countries in the world in terms of liberality and compassion...We subscribe to the principles contained in international treaties...We claim to enforce the laws put in place to protect the rights of [refugees], and especially those pertaining to children. Yet all these lofty ideals become hypocritical nonsense if those policies and sentiments are not translated into action by those who are put in positions of power by the state to do exactly that; who are paid to execute these admirable laws and yet, because of apathy and lack of compassion, fail to do so.

—Judge Anne Marie De Vos, $2004^{1}$

$\int$ ude De Vos's harsh words, directed at representatives from the South African Departments of Home Affairs and Social Development and the South African Police Services for their failure to desist from continuing to detain approximately one hundred unaccompanied foreign minors, both undocumented foreign children and asylum 
seeker/refugee children, at the Lindela Repatriation Centre, encapsulate the challenges that asylum seekers and refugees continue to face in their battle for inclusion in the postapartheid South African state despite the fact that South Africa boasts a progressive legal framework within which the rights of these urban-based asylum seekers and refugees can be respected. However, as much as apathy and lack of compassion have come to characterize the treatment of asylum seekers and refugees in South Africa, I will argue that this sense of apathy and lack of compassion are in themselves the effect of a number of practices adopted by sectors of a nationalist post-apartheid South African state that, despite its commitment to the respect of human rights, evidenced through its adoption of an encompassing Constitution, its accession to international refugee conventions, and its adoption of a rights-regarding Refugees Act, nonetheless is bent on prioritizing the needs of South Africans first and deferring those of non-citizens such as asylum seekers and refugees. While there is no denying the need for the post-apartheid state to produce a sense of unity in the country against an apartheid history of division and dehumanization, the state's production of its citizens is ironically being facilitated by the dehumanization of asylum seekers and refugees and their recurrent portrayal as "bogus" claimants whose intent is to deprive South Africans from enjoying the spoils of their struggles and who should not be in South Africa in the first place. As much as in a country like South Africa it is the government, rather than the United Nations High Commissioner on Refugees (UNHCR), which bears ultimate responsibility for the well-being of asylum seekers and refugees in the country, as illustrated by its willingness to accede to the UN 1951 Conventions, its 1967 Protocol and the 1969 OAU Convention, I will nonetheless argue that UNHCR's practices to safeguard the institution of asylum in South Africa against what it perceives to be either "bogus" claimants or "irregular movers" finds an echo in nationalist practices by a Department of Home Affairs that jointly work to "internally exclude" asylum seekers and refugees, despite their legal protections, and further contribute to their dehumanization.

I rely on the use of the term "internal inclusion" to highlight the dissonance that exists between the rights and protections accorded to asylum seekers and refugees on paper, embodied in South Africa's Constitution, its Refugees Act and the mandate of the UNHCR, and the practical adoption and implementation of policies to give effect to those rights and protections which, informed by nationalist state sentiments and often tacitly supported by UNHCR, serve to undermine the realization of those very same rights and protections. To illustrate how asylum seekers and refugees exist in a state of "internal exclusion" in South Africa, in the first part of this article I provide some background to the urban refugee situation. In the second part, I focus on key government practices that serve to reproduce the internal exclusion of asylum seekers and refugees. In particular, I show how nationalist practices have negatively influenced the ability of asylum seekers and refugees to access refugee reception offices and obtain documentation to secure their stay in the country, as well as the "disabling" types of documents that asylum seekers and refugees are issued and with which they have to secure their survival in the face of no state-provided assistance. The third part of this article focuses on how the UNHCR's policy on urban areas and its quest to safeguard the institution of asylum serve to reproduce asylum seekers' and refugees' state of internal exclusion.

\section{Contextual Background to the South African Refugee Situation}

South Africa is characterized by a non-camp, urban refugee situation where asylum seekers and refugees have freedom of movement within the country. However, their settlement in the country is generally confined to large urban centres such as Johannesburg, Cape Town, Pretoria, Durban, and Port Elizabeth, due to the fact that Refugee Reception Offices, where asylum seekers and refugees have to renew their permits, are located in these major centres. According to the UNHCR, by the year 2000, South Africa had come to host the largest single concentration of urban refugees and asylum seekers in the southern African region, ${ }^{2}$ currently made up of approximately 30,000 recognized refugees and 120,000 asylum seekers, predominantly from African countries.

The South African government's policy towards asylum seekers and refugees is guided by the Refugees Act of 1998, which came into effect in April 2000 after the proclamation of its accompanying regulations, and which is administered by the Department of Home Affairs. In broad strokes, the Refugees Act and its regulations envision the asylum procedure to work as follows. Except in cases where the Minister declares a group or category of persons to be refugees in order to deal with a mass influx, each asylum application is expected to be individually determined. Consequently, a person who wants to apply for asylum needs to complete "without delay" an application form with a Refugee Reception Officer (RRO) in person at one of the established refugee reception offices located inland in five major urban areas, namely, Johannesburg, Pretoria, Cape Town, Durban, and Port Elizabeth. At this time, the applicant is issued with an asylum seeker permit in terms of Section 22 of the Act, which must be renewed until the applicant is asked to return to the refugee reception office to undergo a "nonadversarial” interview with a Refugee Status Determination 
Officer (RSDO), who determines whether to grant or reject refugee status.

Depending on the outcome of the application, the applicant is granted refugee status and subsequently issued a refugee permit in line with Section 24 of the Act, or is given the opportunity to appeal the decision to the Refugee Appeal Board or the Standing Committee, depending on the grounds for rejection. If these two bodies uphold the decisions of the RSDO, the applicant is able to seek judicial review of the decisions by a high court, in line with Section 33 of the Constitution. Keeping these different permutations in mind, the regulations state that asylum applications should be adjudicated or finalized by the Department of Home Affairs "within 180 days of filing a completed asylum application with a Refugee Reception Officer."3

In line with South Africa's Constitution, the Refugees Act explicitly states that recognized refugees enjoy the rights contained in its Bill of Rights, which, unlike many constitutions in the world, not only embodies a bill of justiciable ${ }^{4}$ fundamental civil, political, cultural and socio-economic rights, but also expressly extends most of these rights to "everyone" (who lives in the country) rather than to "every citizen." Important amongst these rights are a person's right to equality and protection against unfair discrimination by the state; as well as the right to inherent human dignity and to have it respected and protected. Linked to these are a number of access rights which include: adequate housing, health care services including emergency medical treatment, sufficient food and water, social security and social assistance, lawful administrative action and information held by the state; as well as direct rights such as the right to education and a number of rights to protect children. Even though, except for the last two rights enumerated, these rights are limited, in the sense that the state must take reasonable legislative and other measures within its available resources, to ensure the progressive realization of each of these rights, these rights nonetheless provide an important safeguard to ensure a basic standard of living and the enjoyment of basic human rights amongst everyone in the country. In other words, despite its limitations and its frequent invocation as the national soul of the country, ${ }^{6}$ the content of the Constitution transcends narrow national boundaries and contains the potential to create a more humane society by asserting the primacy of human beings, whether national or not, whether legally in the country or not. In this regard, the Refugees Act has been hailed as one of the more inclusive pieces of refugee legislation in the Southern African region, as it enshrines freedom of movement, as well as other fundamental civil, political, social, and economic rights, in line with the Bill of Rights of South Africa's Constitution. ${ }^{7}$
However, even though the Constitution embodies this humanist potential, the Constitution has become inserted into a state discourse that asserts its centrality as a key element to unite South Africans first as "equal citizens" against a history of relentless racial discrimination and massive socio-economic inequalities. In turn, giving effect to the rights in the Constitution, and the production of "equal" citizens, has in itself been circumscribed by a macro-economic framework that tends to reproduce the very same inequalities that the state has committed itself to undo. The gap between rising expectations and actual improvements in the lives of the black majority population has served to feed attempts by sectors of the state and society to protect state resources for citizens by excluding foreign others. As a result, its potential to produce a more inclusive political community that incorporates asylum seekers and refugees has been deferred. Instead, it has been up to interested political actors advocating for the rights of asylum seekers and refugees to engage in ongoing struggles to deterritorialize the Constitution, thereby giving substance to its expressed commitment to rights for "everyone."

By way of illustration, the inclusiveness of the Refugees Act had to be fought for and, in my view, heavily influenced by the active participation of civil society representatives in the task team that drafted the Refugees Act. During this drafting process, NGO representatives on the task team had to lobby for the inclusion of refugee rights against recalcitrant representatives from the Department of Home Affairs who held that foreigners did not enjoy any rights in South Africa. ${ }^{8}$ They also had to remind departmental representatives that the Bill of Rights, including its socio-economic rights, applied to "everyone" and not just citizens, while refugees also enjoyed a number of rights as stipulated by international law instruments. Similarly, NGO representatives and UNHCR had to lobby for the inclusion of a hearing as the first step in the determination process, the independence of the status determination structures, the upholding of minimum standards in the arrest and detention of asylum seekers and refugees, and the involvement of civil society in the drafting process. $^{9}$

One particular example of the Department of Home Affairs' attempt to circumscribe human rights and prioritize its citizens was its unsuccessful attempt to institute a system of payment for asylum applications during the drafting of the Refugees Act to distinguish between "real refugees" and "bogus refugees" and recuperate costs, since "[i]t does not help us as a nation to assist others whiles [sic] our own backyard is still in a state of turmoil." 10 Under this system, an amount of money would be refundable to those declared to be "genuine" refugees, "but non-refundable to all abusers of the system" who "would now suffer."11 Asking 
applicants to pay served a dual purpose. It acted as a deterrent to protect the nation from further "infiltration" and ensured that departmental resources remained focused solely on citizens. In its drive to protect its citizens, the Department was not concerned that the majority of applicants, whether genuine or not, would not be able to afford the application fee. Whereas the Constitution, as the highest law of the land, asserted the primacy of all human beings, for the Department of Home Affairs it seemed that some people were, and are, more human than others.

Having fended against these discriminatory incursions, the task team ensured that, at least in law, the "refugee" was to be extracted from the encompassing category of "illegal immigrant." In contrast to the political construction of refugees as "illegal," "invisible," and "out of place" reproduced prior to the drafting of the Refugees Act, the adoption of national refugee legislation had the potential to enable the political construction of refugees as "legal," "visible" bearers of rights that had a "place" within the post-apartheid state, albeit different to, but constitutive of, that of citizens. Unfortunately, however, this potential was seriously circumscribed with the drafting of the refugee regulations almost two years later to enable the practical implementation of the Act.

In contrast to the fairly consultative process followed for most of the drafting of the Refugees Act, the Department of Home Affairs drafted the regulations with minimal public consultation. The latter reflected Thabo Mbeki's shift towards a greater centralization of state power at Cabinet level, once he replaced Nelson Mandela as president in April 1999. ${ }^{12}$ This involved the co-option of political opponents, the elevation of the intelligence portfolio to a full ministry, and an increased silencing of dissenting views. Even though these moves drew heavy criticism from those who believed that a large degree of power was "being wielded largely behind closed doors" 13 with limited accountability, the state defended these moves as a way to improve coordination across different ministries over key service delivery areas. The Refugee Regulations, reflective of state attempts to assert control, defined the character of the permits that would be issued to asylum seekers and refugees, including a provision that prohibited asylum seekers from working and studying during their first six months in the country in the face of no state-provided assistance, and introduced an exclusionary formal identity document for recognized refugees that differed markedly from that issued to citizens. As I will argue, the state's adoption of these measures to give practical implementation to the Refugees Act, coupled to the historical tendency of the Home Affairs Department to neglect its Refugee Affairs section and facilitate access to the asylum procedure, largely set the stage for the reproduction of the state of internal exclusion that asylum seekers and refugees have to endure while in South Africa despite progressive legal protections.

\section{The Battle for Access to Refugee Reception Offices}

Physical access by asylum seekers and refugees to refugee reception offices to lodge asylum applications and renew their permits, particularly in Johannesburg where the largest concentration of asylum seekers and refugees is located, has been an ongoing problem since 1994. While it was expected that these problems would be addressed as the Department of Home Affairs devoted greater attention to refugee matters, this has hardly changed from the time prior to the coming into force of the Refugees Act. In part, the ongoing failure by the Department to take in increasing numbers of asylum seekers and process their applications in a timely fashion is linked to its tendency, over the last ten years, to prioritize services to citizens.

The Department of Home Affairs is entrusted with both the registration and provision of documents to South Africans through its Civic Services branch, and with control over and regularization of population movements, including refugees, through its Immigration branch. This Department, which had historically been responsible for the issuing of passes and implementation of influx control measures against blacks, post-1994 was thrust into the crucial role of ensuring that millions of newly redefined citizens had documents ${ }^{14}$ that would allow them not only to exercise the right to vote but also to entitle them to "enter the struggle for resources," a critical aspect of their demarcation as citizens. ${ }^{15}$ To shift its racist image and enable the production of citizenship, this Department devoted the bulk of its limited human and financial resources to its Civic Services branch, while treating Refugee Affairs as a residual section, exemplified by its existence, until very recently, as one of a number of subdirectorates within its Immigration branch.

The Department's desire to prioritize civic services and its unwillingness to allocate the necessary financial and human resources to its Refugee Affairs section has meant that a large number of newly arrived asylum seekers, who have sought to follow the law and report to refugee affairs offices to lodge their applications, are being forced to remain tenuously in the country without access to any form of documentation for several months or in possession of appointment letters issued by the Department which have limited legal validity, do not count towards the 180 days within which the Department is mandated to adjudicate an application for asylum and are unrecognized by law enforcement authorities. Asylum seekers and refugees lacking 
documents or in possession of expired documents as a result of being unable to gain access to refugee reception offices remain subject to arrest, detention, and possible refoulement under suspicion of being "illegal immigrants." Despite ongoing legal challenges by legal NGOs such as Lawyers for Human Rights and the Legal Resources Centre to force the Department to enable access and issue valid documents to asylum applicants, the Department has not exhibited a sense of urgency in processing new applicants, who often sleep outside refugee offices for nights on end to gain access, even if this constitutes a violation of its own, and international, refugee law. Instead, as the Director of Refugee Affairs recently argued: "Those people sleeping outside-are they genuine asylum seekers? The system is clogged up by illegal immigrants-those people know South Africa, they know how to manipulate the system." 16 In other words, "those people" are not "genuine" anyway, so there is no contradiction in their being possibly subject to arrest and deportation. Neither is there any concern within the Department that if asylum seekers and refugees are not in possession of valid forms of documentation, namely an asylum-seeker or a refugee permit, they are unable to access basic social services such as health, education, and the limited forms of material assistance provided by UNHCR. Thus, even after the introduction of the Refugees Act, the state's actions have actively served to reproduce the equivalence between a refugee and an illegal immigrant and internally exclude asylum seekers and refugees from access to basic forms of protection.

Besides having an impact on access to the asylum procedure, the Department's neglect of refugee matters has also meant that those who are lucky enough to gain access to refugee reception offices and obtain asylum seeker permits have to wait for years for their applications to be decided. Over time, the Department has developed a backlog of undecided applications that includes not only increasing numbers of applicants who have legitimate asylum claims, but also increasing numbers of individuals who, aware of the length of time that it takes the Department to determine an application for asylum, exploit the weaknesses in the asylum system to gain access to, and remain in, South Africa for other reasons. At present, the backlog of undecided asylum applications stands in excess of 100,000, with some of these applications dating as far back as $1998 .{ }^{17}$

Despite the Department's engagement in a protracted status determination process that both enables both the presence of "abusers" in the asylum system and often drives desperate asylum seekers and refugees to engage in corrupt practices to secure access or documentation in the face of perpetual delays, it has become more politically expedient for the Department to portray asylum seekers as fraudsters and abusers of the system who are responsible for the failure of the asylum procedure than to admit that its own practices are working to undermine the asylum procedure. In this regard, whilst a prior Director General of the Department recognized that the protracted application adjudication process had rendered "the refugee system [as] the easy way in," 18 he nonetheless continued to state, on different occasions, that departmental officials often operate under "corrupting influences"19 or a "corrupting pressure," 20 even though he himself recognized that South Africa's immigration service "is a joke." 21 These views continue to be espoused despite the fact that the ex-Deputy Director of Refugee Affairs was fired for "her alleged failure to rein in corrupt subordinates at the country's five refugee reception offices in Johannesburg, Durban, Cape Town, Pretoria and Port Elizabeth." 22 Similarly, the current Minister of Home Affairs, Ms. N. Mapisa-Nqakula, has argued that "particularly non-citizens appear to still have a high level of tolerance for practices that might result in opportunities for corrupt practices to emerge." 23 Thus, it is the nation that is painted as being under threat rather than the state taking responsibility for adopting practices that enable the reproduction of the refugee as "bogus," "corrupt," and a "fraudster" and therefore of their exclusion.

\section{Provision of "Disabling" Documentation for Asylum Seekers and Refugees}

The Refugee Regulations prescribed the types of documents that would be issued to asylum seekers and refugees. As mentioned earlier, asylum seekers would be issued with Section 22 asylum seeker permits while refugees would be issued with Section 24 recognition of refugee status permits, after undergoing an interview with an RSDO and being declared or recognized as refugees. The Refugees Act and its Regulations also indicated that refugees had the right to an ID document but different to the South African one.

\section{Section 22 Asylum Seeker Permit}

The Section 22 asylum seeker permit is an A4 (297 by 210 mm.) flimsy piece of white paper with lettering in black ink, which contains a black and white scanned picture of the applicant, his or her personal details, a case or file number, and a section on conditions applicable to the permit that stipulates, amongst other things, the duration of the permit. Due to the need to renew the permit either every month or every three months, it cannot be laminated. Instead, as a result of the multiple renewals and the requirement for asylum seekers to carry these permits with them at all times, this piece of paper is subject to multiple folds, tears, and fading. Apart from the picture, the permit contains no other security features. 
Until early 2004, when a protracted legal battle put an end to it, the asylum seeker permit's prescribed form had imprinted on it the words "employment and study prohibited" in bold, capital letters. The Department's imposition of this condition meant that during the 180 days or sixmonth period accorded to the Department to adjudicate asylum applications, asylum seekers would be able to neither work nor study. The Department argued that this was necessary not only to deter further movement into the country since "the rights that are accorded to applicants for asylum are abused by persons who are not genuine refugees," but also because allowing asylum seekers to undertake employment would automatically deprive citizens of that opportunity. ${ }^{24}$ The prohibition might have been understandable if the state had taken it upon itself to provide for the basic needs of asylum seekers, in line with its national and international obligations. However, as early as 1997, the Home Affairs Minister had made it clear that the UNHCR, and not the Department, was in the country to provide for the needs of asylum seekers and refugees. As he put it, "[ $\mathrm{t}]$ here is really no problem about refugees in this country...the UN High Commissioner for Refugees...is here to look after their interests." ${ }^{25}$ However, as a later section will show, UNHCR is often more concerned with protecting its own interests than those of its constituency.

Despite the fact that the Department of Home Affairs is the lead government department entrusted with the implementation of the Refugees Act, the Department to this day sees its obligations as being limited to the provision of documentation to asylum seekers and refugees. Beyond these functions, the well-being of asylum seekers and refugees in terms of access to health, education, and social assistance does not concern it. Instead, it is of the view that either UNHCR or possibly other departments such as Health, Education, and Social Development should be approached to deal with the integration of asylum seekers and refugees into these services, particularly into state social assistance and public housing programs that are currently destined for citizens and permanent residents only. However, it has not seen the need to provide leadership in fostering interdepartmental co-operation to address these problems. ${ }^{26}$ Thus in the absence of any state-provided assistance to asylum seekers, the institution of the work and study prohibition left asylum seekers without any legal means to ensure their survival and effectively served to criminalize them and to blur the distinction between asylum seeker and "illegal immigrant" as the former tried to find forms of employment to survive, despite being prohibited from doing so. Asylum seekers could be detained if they contravened the conditions of their permits, could have their permits withdrawn, and could be subject to detention, a fine or imprisonment, or both.

Even though the prohibition was officially abolished in early 2004, the Department continues to this day to use the same forms for Section 22 permits that have already imprinted in them the words "employment and work prohibited," 27 seemingly out of the Department's two-year long inability to redesign the form. ${ }^{28}$ Instead, the currently adopted practice by some officials at refugee reception offices is to simply cross out such words and put their initials next to them ${ }^{29}$ - a practice that simply fuels the sentiment amongst employers and law-enforcement agencies that asylum seekers are criminals who walk around with altered documents, since anyone can grab a pen, cross out the words, and initial next to them. It is, in turn, with these permits - which have to be carried for years on end-that the state claims to be fulfilling its obligations towards the local integration of asylum seekers and that asylum seekers must attempt to subsist in South African society. Despite the permit's shortcomings and its inadequacy in enabling asylum seekers to secure employment, asylum seekers engage in a constant battle to possess it as, at the very least, it provides some protection against arrest, detention and possible deportation.

\section{Section 24 Refugee Permit and Identity Document}

Much like the Section 22 permit issued to asylum seekers, the Section 24 permit is an A4 piece of white paper with black lettering, which contains the logo of the Department of Home Affairs, as well as a photograph, thumbprint, and basic personal details of the applicant. Beyond the picture and thumbprint, the permit neither contains any security features nor is it laminated. Further, due to its size and the requirement that refugees must carry documentation with them at all times, this permit, as in the case of asylum seeker permits, is subject to tears, folds, and fading. The permit also fails to state explicitly that this permit allows refugees, by law, to work and study, which poses ongoing problems for refugees who try to use these permits to secure employment in the face of employers who are unaware of what refugee documents look like, let alone the rights that refugees have during their stay in South Africa.

While the Refugees Act indicated that refugee IDs would be "different," the documents outlined in the Regulations turned out to be significantly different from documents issued to South Africans or permanent residents. South African ID documents are green-covered booklets that have a 13-digit bar-coded number and a number of pages, whereas ID documents issued to refugees are maroon in colour and do not have any pages inside. In a country where the 13-digit bar-coded green South African identity docu- 
ment is the key to access public services and to integration, the Department assumed that "abusers" of the system would gain access to these valuable IDs and therefore to valuable services seen to be destined for citizens. ${ }^{30}$ The state's issuing of maroon ID to refugees has served to reinforce an important "internal exclusion," by effectively denying them access to publicly provided services and employment. ${ }^{31}$

Despite the Department's encompassing discourse of solidarity and empathy, and its supposed attempts at "humanising" 32 and giving dignity to refugees by issuing them with very different-looking documents, refugees generally have seen these documents as further attempts by the state to keep them as "outsiders." Some, quite rightly, have noted that these documents resemble the passes that used to be issued to Africans under apartheid. As one refugee put it, if indeed the Department aimed to give dignity to refugees then "why give a document that is physically different to those carried by South Africans?... It invokes the image of pass documents-after all, the apartheid police did think it may be giving dignity." ${ }^{3} 3$ Similarly, other refugees have pointed to the contradictions of this practice by stating that "[o]fficially [the Department] want to integrate us, but now we're getting a red refugee book in contrast to the green South African identity document... They want to label us as different." 34

The issuing of identity documents markedly different from those issued to South Africans and unknown amongst administrators in most public and private institutions, including employers, in practice has meant that refugees continue to be further "dehumanised," as the Department seeks to delineate an "inside" of citizens that needs to be protected from the outside refugee threat. In this regard, even though some departmental officials have tried to argue that there was "nothing sinister" 35 in issuing a different-coloured document to refugees, the rationale behind it was predominantly focused on control and differentiation between refugees and citizens rather than on producing an "enabling" document for refugees. ${ }^{36}$ The Department has made very few attempts to popularize these documents, or any documents it issues to asylum seekers, and thus allow asylum seekers and refugees to be integrated into South African society. ${ }^{37}$

The character of the documentation issued to asylum seekers as well as refugees, and particularly its distinctiveness in relation to documents issued to citizens and residents, militates against their ability not only to sustain themselves in the absence of any state-provided assistance, but also to contribute their skills to a South African economy that is facing massive shortages as a result of decades of inadequate apartheid education. In this regard, results from the most comprehensive national survey conducted with 1,500 African asylum seekers and refugees in the country in 2002 and 2003 showed that two-thirds of asylum seekers and refugees interviewed nationally had at least completed secondary education..$^{38}$ In particular, almost one-third had completed tertiary education, namely, undergraduate or graduate degrees, but only 3 per cent managed to obtain employment in skilled occupations after their arrival in South Africa. ${ }^{39}$

In sum, despite the state's formal (but always incomplete) compliance with both national and international law in the issuing of different forms of documentation to asylum seekers and refugees, its issuing of flimsy permits to asylum seekers which, despite numerous court actions, continue to deny them the right to work and study, coupled to unjustifiable delays in the issuing of red, albeit formal, identity documents to refugees which are unrecognizable by most private and public institutions, including employers, has ensured that asylum seekers and refugees remain internally excluded from access to the South African state and kept at bay from posing a threat to the nation. Moreover, these practices by the Department have cumulatively worked to reproduce a political construction of asylum seekers and refugees as "criminals," as they are often driven to engage in extralegal activities to ensure their survival; as "invisible" or "subhuman," as they are denied their right to have their basic human dignity respected; and as "out of place," as they are issued with documents that reinforce that they are not from "here."

Yet, despite the Department's ongoing attempts to exclude asylum seekers and refugees, these groups have continually shown their resilience by finding ways of circumventing the numerous obstacles enabled by state practices in their quest for survival, through a reliance on country or region-based refugee networks and participation in informal sector activities such as street trading and car watching. This quest for increasing self-reliance to ensure their survival has not only been necessary to defend against exclusionary state practices, but also against exclusionary practices by the UNHCR, which, ironically, in the eyes of many asylum seekers and refugees should be their "protector" in South Africa.

\section{The Contested Mandate of the UNHCR in South Africa}

Towards an Understanding of UNHCR's Mandate in Urban Areas

An understanding of UNHCR's approach towards dealing with an urban refugee situation such as that found in South Africa must be cognizant of two main factors. Firstly, as an organization set up by the United Nations, with the support 
of individual countries, UNHCR serves to reproduce the international system of states premised on a congruence between state, territory, and people. As an agency entrusted to deal primarily with large population displacements, the aim of the UNHCR is to ensure that disturbances to this congruence are contained as much as possible and eventually eliminated through the pursuit of voluntary repatriation upon the cessation of conflict, as the preferred and best long-term solution. ${ }^{40}$ For the UNHCR (and the countries that fund it), ensuring the success of this policy requires that "individual refugees and groups remain as close as possible to their country of origin... or at least in a culturally and/or linguistically familiar environment." ${ }^{41}$ Secondly, and to uphold these objectives, the general, and cost-effective, practice of the UNHCR has been to set up camps, particularly where conflicts have led to large population movements, situated geographically close to such areas of conflict where large numbers of refugees can be offered protection as a group, as opposed to being treated on an individual basis.

However, the increased individual, rather than en masse, refugee movements in the 1990s to urban areas away from camps prompted UNHCR to devise a policy to address these specific situations in a coherent way. The resultant UNHCR policy on refugees in urban areas has been driven by its desire to contain both movements to urban areas, and thus further away from what UNHCR considers "the familiar environment" of refugees, as well as the disproportionate costs incurred by UNHCR as it tried to deal with those in urban areas on an individual basis, ${ }^{42}$ while donors "show[ed] little enthusiasm for long-term care and maintenance of urban cases." 43 Thus, from the start, it would seem that driving forces for the urban policy have been containment and the concomitant rationalization of financial resources balanced against a commitment to ensure the protection of refugees, regardless of location.

This tendency to regard camp-based situations as the norm against which to address the needs of refugees is exemplified by the UNHCR's definition of urban caseloads as being derivative from camp-based caseloads. Assuming that the majority of refugees should be cared for in nearby camps, UNHCR envisions that only a minority should be allowed to move to urban areas in another country where usually there are no camps-or within the same country where a camp is located-only on the basis of compelling reasons, such as protection or security problems in camps or settlements, as well as family reunification. If such compelling reasons do not exist, then those who move to urban areas in other countries should be regarded as "irregular" movers. ${ }^{44}$ As defined by both the December 1997 UNHCR urban refugee policy and UNHCR Excom Conclusion No. 58 (1989), "irregular movers" are refugees or asylum seek- ers who move, without the consent of authorities concerned and therefore irregularly, from a country where they had found protection to another country. "Irregular movers" are often portrayed as individuals who, despite having valid asylum claims, engage in "asylum shopping" in search of better economic opportunities rather than protection, since UNHCR's assumption is that protection has already been provided in the first country of asylum, usually through camps or rural settlements, even if very often this is not the case. To re-establish its desire for order, UNHCR policies recommend that "irregular movers" should be returned, where feasible, to their first country of asylum. As will be discussed further on, since often this is not possible, UNHCR's assistance policy is aimed to discourage further "irregular" movement to urban areas.

\section{Protection and Assistance to Asylum Seekers and Refugees} in Urban Areas

Regardless of whether asylum seekers and refugees find themselves in urban areas as a result of regular or irregular movement, UNHCR's December 1997 policy states clearly that its "over-riding priority remains to ensure protection, and in particular, non-refoulement and treatment in accordance with recognized basic human standards." ${ }^{45}$ In this regard, in urban settings where usually no camps exist, and until durable solutions such as voluntary repatriation or resettlement can be exercised, UNHCR is mandated to pursue the local integration of asylum seekers and refugees as an alternative third durable solution, premised on two assumptions, namely, "state obligation for protection and assistance" and "refugee self-reliance." 46 Unlike in many camp-based situations where the UNHCR is the sole provider for the needs of refugees in the absence of a wellfunctioning state, in urban-based situations, and particularly those where states have become signatories to refugee conventions, UNHCR expects that states will exercise their responsibilities to asylum seekers and refugees. To facilitate this, UNHCR's protection objectives enjoin it to engage in "strenuous and continuing interventions... with host governments...to encourage them to grant recognized refugees access to employment/the labour market; national hospitals, schools and other social services (at rates equivalent to those paid by nationals); and, the naturalisation process." 47

To fill the gap that might exist until states take up their obligations to asylum seekers and refugees in urban areas, the December 1997 urban refugee policy indicates that, under certain circumstances, UNHCR should provide material assistance that is time-limited, "that encourages selfreliance and does not foster long-term dependency." 48 However, it absolves the UNHCR from the provision of assistance to "irregular movers," by arguing that UNHCR 
"does not have an obligation to provide assistance to refugees after irregular movement on the same basis as it would had there been no irregular movement." 49 The only exceptions are cases where life-saving assistance is not available from other sources or where the lack of UNHCR assistance would compromise its protection objectives. Besides limited emergency assistance, the policy states that UNHCR should provide solution-oriented assistance to promote self-reliance, amongst recognized refugees, "in a manner that will depend on local circumstances." 50

\section{Role of UNHCR and Implementation of Its Policy on Refugees in Urban Areas in South Africa}

The UNHCR in South Africa tends to operate within two contradictory discourses. At an international and national public level, the UNHCR in South Africa projects an image of caring for asylum seekers and refugees, as per its mandate. However, lurking below UNHCR's public face-and echoing the practices of the Department of Home Affairs-lies a discourse that represents asylum seekers and refugees in South Africa negatively, as "chancers" and "bogus" asylum claimants. This discourse emanates from a belief amongst UNHCR staff in South Africa that a large proportion of applicants who seek asylum in South Africa are applicants whose cases are likely to be manifestly unfounded, abusive, or fraudulent. To illustrate, comparing asylum seekers and refugees present in South Africa to those found in other countries, one UNHCR representative explained that "refugees in Zambia are refugees, refugees in Zimbabwe are refugees... [but] $80 \%$ of the people should not be here." 51 This is echoed in the UNHCR's 2004 global report for South Africa, which states that "among the many pending applications, as many as 80 per cent originate from non-conflict countries." 52 While it might be the case that upon undergoing status determination with an RSDO, some or many of the claims made by asylum seekers are indeed found to be manifestly unfounded, this can only be known with certainty once the state undertakes this individual status determination process and the grounds upon which the claims are made are thoroughly considered. This much, the UNHCR recognizes; however, despite this acknowledgement, it is nonetheless of the view that "you might have the odd person who has a valid individual claim but those are the exceptions in the vast majority of cases." 53 Added to this, UNHCR holds, despite the absence of proof to corroborate this, that the large majority of the remaining 20 per cent of asylum applicants who have "genuine" or founded asylum claims are nonetheless "irregular movers." ${ }_{4}$ Thus, whether asylum applicants have genuine claims or not, for the UNHCR they tend to be deviant and a close relative to "illegal immigrants," either because their claims are pre- sumed to be "manifestly unfounded" or, despite having legitimate asylum claims, because they are "irregular" movers. By classifying those in South Africa who might have valid claims predominantly as irregular movers, UNHCR also does not have an obligation to provide assistance, but may do so to meet minimum standards.

This belief by UNHCR that, even after an individual status determination process, only a few applicants would be "bona fide" or "genuine" cases, serves to create a culture of suspicion amongst UNHCR staff towards all asylum seekers and refugees in South Africa which converges with that espoused by the Department of Home Affairs, even if they are protecting different terrains. While the UNHCR argues that "these people should not even be here!" as part of UNHCR's quest "to preserve the space that is refugee protection," 55 the Department of Home Affairs does not want "these people here" in the face of "growing expectations of our nationals." 56 As I have argued elsewhere, the tendency to see a potential abuser lurking behind every asylum seeker not only feeds a mentality within both government and UNHCR that asylum seekers and refugees should be seen as "guilty until proven innocent" but also, and in the process, helps to foster broader societal xenophobic reactions towards asylum seekers and refugees, irrespective of the validity of their claims. ${ }^{57}$

\section{UNHCR's Interventions with the Department of Home Affairs}

While both UNHCR and the Department assert that there is widespread "contamination" of the asylum procedure, they have adopted different ways of trying to close the loopholes in the system. For the state this has translated into contested attempts to deter people from entry into the asylum system in the first place as a way to protect its own citizens. These have included active attempts to impose boundaries of exclusion not only at South Africa's geographical borders to limit the initial movement of asylum applicants into the territory, but also, and as shown earlier, internal boundaries by preventing the entry of asylum applicants into refugee reception offices and by refusing to issue asylum applicants with documentation (or issuing them with documentation that has made it as difficult as possible for asylum seekers and refugees to subsist in the country).

While UNHCR might privately agree with some of the initiatives undertaken by the state to control access to the asylum procedure in the first place, ${ }^{58} \mathrm{UNHCR}$, whose mandate is to protect and advocate for the rights of asylum seekers and refugees, cannot be seen publicly as condoning the denial of any human being to apply for asylum. Instead, UNHCR has sought to protect this institution of asylum by 
ensuring that the procedure adopted and implemented by the South African state itself can act as a tight and effective screening mechanism. In other words, while the state has sought to exclude applicants before they enter the asylum system, UNHCR has adopted practices to ensure that the proper implementation of the Refugees Act can produce these exclusions premised on the notion that a fast, efficient, and credible system that can quickly process applications represents a good deterrent against abuse. This serves to explain UNHCR's targeting of a large part of its interventions with the South African state on the Department of Home Affairs. These interventions, which have tended to take place away from the public eye, have included: capacity building and advice on status determination procedures based on international "best practice," through the ongoing training of government officials on refugee law and protection; and provision of equipment, such as computers and printers, as well as resources to expedite the issuance of refugee identity documents and the asylum determination procedure. ${ }^{59}$

However, the UNHCR has been less willing to take active steps to raise concerns that might have a direct impact on the lives of asylum seekers and refugees. For instance, the UNHCR has been slow to intervene in raising problems of access to the refugee reception offices. ${ }^{60}$ To date, it has also not prioritized working with the Department to initiate a public information campaign to make employers, banks, and government institutions aware of the right of asylum seekers and refugees to work, as well as of the types of documentation that asylum seekers and refugees are being issued, including the maroon refugee ID.

The perceived unwillingness of the UNHCR to play a more active role in ensuring the protection of those it is mandated to protect needs to be understood within UNHCR's desire to safeguard the institution of asylum against those who are not presumed to be "genuine" refugees. Within this context, advocating for greater access of asylum seekers to refugee reception offices and integration of asylum seekers whose cases are still pending, before a "proper" asylum determination procedure is in place, could enable the further "contamination" of the asylum determination procedure. So, as much as UNHCR works with the Department of Home Affairs to protect the rights of asylum seekers and refugees, the character of its interventions is selective and aligned with its desire to keep "clean" the institution of asylum first.

While asylum seekers and refugees regularly highlight the limited assistance and support that they receive from the UNHCR, UNHCR assumes that if asylum seekers with valid asylum claims made it all the way to South Africa, regardless of the hardships that they might have endured, it must mean that they are either self-reliant or must learn to be so since they "chose" to come to this country. ${ }^{61}$ This perception also reinforces the notion that "real" refugees are the poor victims who stay behind in camps, whereas those who exercise a sense of agency in trying to improve their situation as refugees-as any human being would want to do-are not. Equating urban-based refugees with being self-reliant and with not being "real" refugees does not allow for the possibility that "real" refugees who have valid reasons to be in South Africa might need assistance while they struggle to be self-reliant.

The inadequacy of confining UNHCR emergency assistance to a period of three months when status determination can take years is compounded by a situation where UNHCR provides extremely limited solution-oriented assistance to recognized refugees, mainly in the form of language courses and some vocational training. Thus a situation exists in South Africa where, not only is emergency assistance inadequate due to its time limitation and strict criteria, but also UNHCR has not undertaken sufficient action to provide solution-oriented forms of assistance, as per the global urban refugee policy. Even though UNHCR has played an important role in facilitating the issuing of documents to refugees, it has neither taken steps with the government to ensure that employers become aware and accept these documents, nor advocated for the integration of refugees into employment. Further, despite the claims in the urban refugee policy that UNHCR should develop capacity to promote self-employment activities amongst refugees, UNHCR has made limited inroads in establishing contacts with key government departments to explore the possibilities of incorporating refugees into micro-credit facilities, the setting up of small businesses, or facilitating other avenues for self-employment and enabling them to utilize their much-needed skills. ${ }^{62}$ As discussed earlier, its main focus has been on safeguarding the institution of asylum first, to ensure that those who access the asylum procedure and its protection are "real" refugees. In the meantime, asylum seekers and refugees are becoming self-reliant not because of, but in spite of, the activities carried out by the UNHCR and the South African state. Asylum seekers and refugees have managed to find ways of taking charge of their own immediate destinies, by providing support and accommodation and by opening possible employment opportunities to fellow asylum seekers and refugees.

\section{Conclusion}

As asylum seekers, refugees, and organizations working with them have struggled, through their day-to-day practices and reliant on the inclusive framework of the Refugees Act and 
the Constitution, to reaffirm a political construction of refugees as political actors with legal standing, with visible rights that need to be respected and as persons entitled to have a place in the new South Africa, the practices of UNHCR have worked to undermine this construction as it continues to represent refugees, echoing the nationalist-inspired practices of the Department of Home Affairs, as agentic "fraudsters" or "bogus claimants," who have no place in South Africa, for either their asylum claims are seen to be "manifestly unfounded" or they have exercised their agency and have become "irregular movers." While the UNHCR as the "refugee protector" would likely deny its role in reproducing a "culture of suspicion" towards asylum seekers and refugees in its quest to protect the institution of asylum, this "culture of suspicion" has come to find resonance amongst sectors of the state, key amongst these the Department of Home Affairs, which wants to limit the inclusion of asylum seekers and refugees to a bare minimum on behalf of its "new citizens" and despite an encompassing legal framework that explicitly affirms the human dignity of every person. As much as UNHCR might claim that its interventions represent forms of "apolitical" advice to the South African government, the selective practices adopted by the UNHCR are having a direct political impact on, and militating against, the ability of asylum seekers and refugees to gain visibility as political actors in the eyes of a Department of Home Affairs that defiantly justifies its apathy and lack of compassion against ongoing contestations by NGOs, asylum seekers, and refugees. While in the short term it will be up to NGOs, together with asylum seekers and refugees, and a progressive judiciary to fight for the humane treatment of asylum seekers and refugees in South Africa, in the longer term these struggles will require linking up with broader societal struggles affecting South Africa's poor majority out of a realization that the economic forms of exclusion between rich and poor that we currently face do not distinguish between citizens and non-citizens.

\section{Notes}

1. Centre for Child Law vs. Minister of Home Affairs and Others 2005 (6) SA 50 (T), para 30, 14.

2. UNHCR, UNHCR Global Appeal 2000: Southern Africa Regional Overview (Geneva: UNHCR, 2000), 105.

3. Refugee Regulations (Forms and Procedure) 2000, Government Gazette No. 21075, 6 April 2000 (Pretoria: Government Printer, 2000), Section (3)(1), 6.

4. South Africa is one of the few countries in the world that has agreed to incorporate a list of directly enforceable socio-economic rights in its Constitution. While countries such as Namibia, Brazil, India, and Ireland recognize socio-economic rights, they do so as directive principles of state policy which are not directly enforceable by courts, even though they should be considered when interpreting legislation or drafting laws. In contrast, in South Africa, the courts can be relied upon not only to ensure that the state does not infringe negatively on socio-economic rights, but also, and more importantly, to assess the degree to which the state is meeting its positive obligations to realize these rights. J. de Waal, I. Currie, and G. Erasmus, The Bill of Rights Handbook, $3^{\text {rd }}$ ed. (Pretoria: Lawyers for Human Rights and Law Society of South Africa, 2000), 399-401.

5. Rights that are expressly circumscribed to citizens include the right to vote (Section 19); the right to enter, to remain in, and to reside anywhere in the Republic (Section 21); and the right to choose a trade, occupation, or profession freely (Section 22). Even though Section 21 would seem to limit the right of refugees to enter and remain in South Africa, Section 39(1)(b) states that in interpreting the Bill of Rights, a court, tribunal or forum "must consider international law." See Constitution of the Republic of South Africa, Act No.108 of 1996 (Pretoria: Government Printer, 1996). In this regard, the state must give due regard to international refugee law instruments such as the UN 1951 Convention and the OAU 1969 Convention on Refugees.

6. N. Mandela, "Address by President Nelson Mandela to the Constitutional Assembly on the occasion of the adoption of the New Constitution" (Cape Town, 8 May 1996), <http:// www.anc.org.za/ancdocs/history/mandela/1996/ sp960508.html> (date accessed: 16 March 2006).

7. See Legal Resources Foundation, A Reference Guide to Refugee Law and Issues in Southern Africa (Lusaka: Legal Resources Foundation, 2002) for a comparison of refugee legislation in different Southern African countries.

8. B. Vantyu, "Report of the White Paper Task Team," (Pretoria: Lawyers for Human Rights, 1998), 2.

9. Ibid., 3. Even though the Aliens Control Act stipulated that individuals should be detained for a period of thirty days, which could be extended to a further thirty days subject to review by a High Court, the Department wanted asylum seekers and refugees to be detained for a continuous period of ninety days if their status were to be withdrawn.

10. Department of Home Affairs, "Comments/Inputs on the Draft Refugee White Paper” (Pretoria: Sub-Directorate for Refugee Affairs, 1998), 4.

11. Ibid. (emphasis added).

12. A number of commentators raised concerns about the formation of a loyalist Mbeki cabal within Cabinet, with the President's personal friend as the Minister of Government attached to the President's Office. As Mbeki came to power, he strategically placed a series of hand-picked confidants to effect transformational changes in key portfolios, and agreed to centralize the flow of government information and propaganda, amongst other measures. See "Mbeki's Lean, Mean Ruling Machine," Mail \& Guardian, 25 June to 1 July 1999; "Mbeki's Co-option tactic Cannot Roll Back Intolerance Alone," Sunday Independent, 4 July 1999; W. M. Gumede, 
Thabo Mbeki and the Battle for the Soul of the ANC (Cape Town: Zebra Press, 2005).

13. "Mbeki’s Lean, Mean Ruling Machine," Mail \& Guardian, 25 June to 1 July 1999.

14. To illustrate, in 1993 a total of 2,423,075 identity documents were issued, whilst a similar number $(2,116,600)$ were issued between January and April 1994. See M. Buthelezi, Minister of Home Affairs, "Appropriation Bill: Debate on Vote No. 29-Home Affairs," Debates of Parliament (Hansard), National Assembly, Proceedings of Extended Public Committee, 9 August 1994, col. 1023.

15. M. Mamdani, "African States, Citizenship and War: A CaseStudy," International Affairs 78, no.3 (2002), 505.

16. Ms. B. Mkhwebane-Tshehla, Director for Refugee Affairs, response to a question on the steps taken by the Department to address problems of access to the Rosettenville and Pretoria refugee reception offices, at a meeting held with the NCRA on 4 July 2005, Kutlwanong Democracy Centre, Pretoria.

17. "Statement by Acting Deputy Director General: National Immigration Branch, Mr. Gcinumzi Ntlakana on the Refugee Backlog Project at the Court Classique Hotel" (Department of Home Affairs, Pretoria, 20 April 2006), 1, ttp://www.home-affairs.gov.za/speeches.asp?id=157 (accessed 29 April 2006).

18. B. Gilder, Director-General's Media Briefing (Sandton, 5 November 2003), 3, <http://www.home-affairs.gov.za/speeches. asp?id $=76>$ (accessed 3 July 2005).

19. B. Gilder, Director General, Department of Home Affairs, Special Assignment, SABC 3 Television (Johannesburg, South Africa), 22 February 2005.

20. B. Gilder, Director-General's Media Briefing, 5.

21. "Home Affairs Boss Paints Bleak Picture," [Johannesburg] Star, 6 November 2003.

22. "Wits Fingers Home Affairs on Corruption," Cape Argus, 11 December 2004. The Special Assignment program cited above also showed officials from the Department facilitating the acquisition of fraudulent documents by foreigners from their homes, after hours. For a deposit of 850 rands and a further fee of 1,500 rands, these officials used departmental forms and took fingerprints of applicants to enable them to receive their South African ID documents in less than three months. These officials were arrested and dismissed shortly after the program's airing.

23. N. N. Mapisa-Nqakula, Minister of Home Affairs, Statement on the Occasion of the Release of a Report on Finalised Cases of Corruption and Misconduct, Pretoria, 18 July 2005, (Pretoria: Ministry of Home Affairs, 2005), 1.

24. Minister of Home Affairs and Others vs. MW Watchenuka and Cape Town Refugee Centre, Case No. 10/03, S. Afr. S.C., Judgement, 28 November 2003, para. 33, 14-15.

25. M. Buthelezi, "Introductory Speech to Home Affairs Budget Debate," Debates of Parliament (Hansard), National Assembly, Proceedings of Extended Public Committee, 17 April 1997, Vol. 13, col. 1320.

26. In an interview with Head of the Refugee Affairs Sub-Directorate, she argued that inter-departmental coordination was "not a problem" because key departments met on a quarterly basis through the Inter-Departmental Disaster Management Committee. However, this Committee is tasked only with emergency situations and does not deal with inter-departmental coordination in non-emergency cases (Interview by the author, Pretoria, 28 March 2001).

27. N. Ngozwana, Acting Head, Rosettenville Refugee Reception Office, "Address to the Forced Migrants in Johannesburg Working Group," Graduate School for the Humanities and Social Sciences, Wits University, Johannesburg, 15 March 2005.

28. This is also not the first time that the Department has relied on administrative factors as justifications for non-compliance with the law. In a letter of complaint to the Public Protector, the Wits Law Clinic pointed out: "On many occasions people are turned away from the office without receiving any service from officials inside. Officials state that 'the printer is not working'; 'we cannot access the computer system because we haven't got appropriate codes'; and other technical faults... [T] hese problems happen with such regularity as to make them seem almost a deliberate obstruction of administrative justice." Wits Law Clinic, "Letter of Complaint on the treatment of asylum seekers and refugees at the Braamfontein Refugee Reception Centre (Department of Home Affairs)," unpublished, 2-3.

29. G. Singh, Accessing Rights: Crisis and Corruption at the Rosettenville Refugee Reception Office (Johannesburg: Forced Migration Studies Programme, Wits University, 2005), 10.

30. Department of Home Affairs, "Comments/Inputs on the Draft Refugee White Paper," Section 4.7, 3.

31. While willing to give refugees ID documents that would go largely unrecognized amongst formal employers, the Department argued that refugees should not be allowed to engage in hawking but that hawking "should be reserved for citizen [sic] as this normally [sic] a point of conflict between citizens and aliens," despite this being an important source of livelihood for many asylum seekers and refugees who cannot access formal employment. Ibid.

32. B. Masethla, Director General, Department of Home Affairs, "Address at the Launch of Identity Documents for Refugees," Yeoville Recreation Centre, Johannesburg, 7 April 2001.

33. Mail \& Guardian, "Pass Books for Refugees," 22 to 28 June 2001.

34. "South Africa: New Asylum Regulations Anger Refugees," 9 April 2001, <http://www.reliefweb.int/w/rwb.nsf/s/FCFB57A 909865D1E85256A2A004F9D52> (accessed on 2 May 2004).

35. It is interesting that this individual saw the need to justify that there was nothing sinister about issuing different documents to refugees in answer to the question: "Why were different documents issued to refugees?"

36. Mr. C. Schravesande, Chairperson, Standing Committee for Refugee Affairs, interview by the author, Pretoria, 12 May 2005. Mr. Schravesande explained that "the intention was that anybody looking at the document would know exactly right from the start, what kind of document it is...the colour of the

(C) M. Florencia Belvedere, 2007. This open-access work is licensed under a Creative Commons Attribution-NonCommercial 4.0 International License, which permits use, reproduction and distribution in any medium for non-commercial purposes, provided the original author(s) are credited and the original publication in Refuge: Canada's Journal on Refugees is cited. 
document would be telling you that in the first place. So that is just a separation of the rights, so that somebody would know what rights which document has." Similarly, another official argued that "there were people who might have thought that it would be useful to differentiate between refugees and nonrefugees, to easily identify them." R. Sikakane, Assistant Director, Refugee Affairs Sub-Directorate, Department of Home Affairs, interview by the author, Pretoria, 26 April 2005.

37. When asked about attempts by the Department to communicate with employers about the documents issued to asylum seekers and refugees, the Chairperson of the Standing Committee for Refugee Affairs stated: "Not a whole lot. There have been a few occasions where Home Affairs or the Ministry has had a public platform where they mention that, but not to a great extent..." (Interview by the author, Pretoria, 12 May 2005).

38. M. F. Belvedere,, E. Mogodi and Z. Kimmie. National Refugee Baseline Survey: Final Report (Pretoria: CASE, UNHCR, and JICA, 2003), 45.

39. Ibid., 52.

40. Resettlement of individual refugees to other countries also constitutes a long-term solution, particularly in protracted refugee situations, for the purposes of family reunification, or where refugees might continue to experience security concerns or persecution even after fleeing to a safe nearby country.

41. UNHCR, UNHCR Policy on Refugees in Urban Areas, 12 December 1997, 4 .

42. In a 1995 discussion document, UNHCR argued that while urban refugee caseloads accounted for less than 2 per cent of the total number of refugees under its care, they nonetheless consumed between 10 per cent and 15 per cent of the organization's human and financial resources. C. Mougne, UNHCR's Policy and Practice Regarding Urban Refugees: A Discussion Paper (Geneva: UNHCR Inspection and Evaluation Service, 1995), 2.

43. UNHCR, UNHCR Comprehensive Policy on Urban Refugees, 25 March 1997, 5.

44. UNHCR has become increasingly concerned about irregular migration, particularly as a result of an increase in restrictive immigration policies and measures in Northern countries. UNHCR, Refugee Protection in International Law: UNHCR's Global Consultations on International Protection (Cambridge: Cambridge University Press, 2003), 5; see also J. Vedsted-Hansen, Europe's Response to the Arrival of Asylum Seekers: Refugee Protection and Immigration Control, New Issues in Refugee Research Working Paper No. 6 (Geneva: Center for Documentation and Research, UNHCR, 1999).

45. UNHCR, UNHCR Policy on Refugees in Urban Areas, 12 December 1997, Inter-Office Memorandum No.90/97, Field Office Memorandum No.95/97 (Geneva: UNHCR, 1997), 3.

46. UNHCR, UNHCR Comprehensive Policy on Urban Refugees, 25 March 1997, Inter-Office Memorandum 25/97, Field Office Memorandum 30/97 (Geneva: UNHCR, 1997), 12; UNHCR, UNHCR Policy on Refugees in Urban Areas, 12 December 1997, 4.
47. UNHCR, UNHCR Comprehensive Policy on Urban Refugees, 25 March 1997, 12.

48. UNHCR, UNHCR Policy on Refugees in Urban Areas, 12 December 1997, 4.

49. Ibid., 7.

50. Ibid.

51. UNHCR Representative, interview by the author, UNHCR offices, Pretoria, 24 March 2005.

52. UNHCR, UNHCR Global Report 2004 (South Africa), (Geneva: UNHCR, 2004), 296.

53. UNHCR Representative, interview by the author, UNHCR offices, Pretoria, 24 March 2005.

54. UNHCR, UNHCR Policy on Refugees in Urban Areas: On Minimum Standards for Assistance to Urban Refugees/Irregular Secondary Movers (Pretoria: UNHCR, February 2005), 1. This document was distributed at UNHCR's 2006 Strategic Planning Workshop held on 14-15 February 2005, Pretoria.

55. UNHCR Representative, interview by the author, UNHCR offices, Pretoria, 7 March 2005.

56. M. Buthelezi, Inaugural Address at the Regional Conference on 'The 1951 Convention at Fifty: The Way Forward,' hosted by the International Association of Refugee Judges, Centurion, Pretoria, 12 July 2001, 4.

57. See M. F. Belvedere, "Submission by the Community Agency for Social Enquiry (CASE) to the Open Hearings on Xenophobia and Problems Relating to It to be hosted by the SAHRC together with the Portfolio Committees of Foreign Affairs and Home Affairs," 28 October 2004; and South African Human Rights Commission, Report on Open Hearings on Xenophobia and Problems related to it (Johannesburg: SAHRC, 2004).

58. It is important to point out that UNHCR was opposed to contesting the denial of asylum seekers to work and study as a measure to prevent abuse of the system, while it has been the UNHCR that recently advised the Home Affairs Department to do something to clean up the queues of prospective asylum applicants.

59. In this regard, a March 2005 unpublished draft of the Standard Operating Procedures (SOPs) for Refugee Affairs, drawn with the support of the UNHCR, contains twenty full pages that provide "tips" on how RSDOs should assess the credibility of an applicant based on objective evidence and the internal consistency and logic of an applicant's testimony. Amongst its tips, the SOPs state that RSDOs should refrain from considering other applicants' stories as "objective evidence" of the conditions in a country of origin "as it is conceivable that other applicants may be fabricating similar claims” (29). They also enjoin the RSDO to "be alert as there may be something that the applicant does not want...to tell you" (41). RSDOs then, must be able to show that applicants are "real" refugees at the end of the process. Department of Home Affairs, National Immigration Branch, Standard Operating Procedures for Refugee Affairs, Version 2, 29 March 2005 (unpublished).

60. The Forced Migration Working Group in Johannesburg in June 2005 asked UNHCR about the steps it had taken to address the closure of the refugee reception office in Johannes- 
burg to newcomers with the Department since this presented a serious protection problem. In an e-mail response received on 20 June 2005, the UNHCR stated the following: "We are concerned that this is causing hardships to the asylum seekers. That said the department has indicated to us that they are in a process of looking for more durable solutions." In other words, beyond being concerned, UNHCR decided to wait for the Department to resolve the issue in its own time.

61. UNHCR-South Africa, Refugees \& Asylum Seekers: How to Access Social Assistance, (Pretoria: UNHCR-South Africa, 2005), 3.

62. In 2002, the UNHCR commissioned research to evaluate the limited small business programs provided by three of its implementing partners and to provide a basic framework to develop self-reliance strategies for refugees. See: Resolve Worldwide, Report to UNHCR on Proposed Micro-lending and Income Generation Model for Refugees in South Africa (Cape Town: Resolve Worldwide, 2003), 2. This initiative, however, has not been followed up due to resource constraints.
M. Florencia Belvedere, Ph.D., is an Honorary Research Associate at the Forced Migration Studies Programme, University of the Witwatersrand.

(C) M. Florencia Belvedere, 2007. This open-access work is licensed under a Creative Commons Attribution-NonCommercial 4.0 International License, which permits use, reproduction and distribution in any medium for non-commercial purposes, provided the original author(s) are credited and the original publication in Refuge: Canada's Journal on Refugees is cited. 